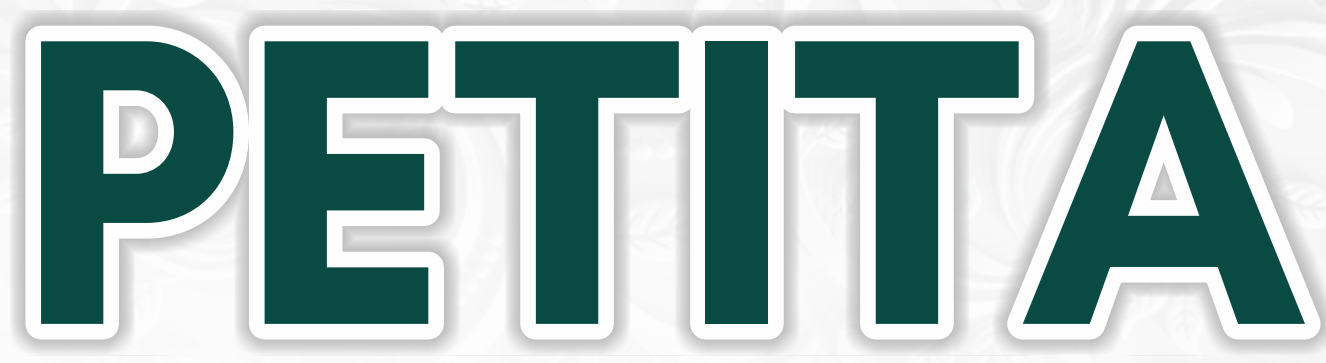

Jurnal Kajian Ilmu Hukum dan Syariah

Published By:

Lembaga Kajian Konstitusi Indonesia (LKKI)

Fakultas Syariah dan Hukum Universitas Islam Negeri (UIN) Ar-Raniry Banda Aceh Jl. Syeikh Abdul Rauf, Kopelma Darussalam Banda Aceh, Telp: 0651-7557442 Website: http://petita.ar-raniry.ac.id 


\section{Contents}

EKSISTENSI BITCOIN DALAM PERSPEKTIF MAQĀṢID AL-SYAR'ĪYAH

(Dara Lidia, Jabbar Sabil \& Syarifuddin Usman / 104-113)

TATACARA PENETAPAN BATAS TANAH DIKALANGAN MASYARAKAT KECAMATAN BAKONGAN TIMUR DITINJAU MENURUT KONSEP MAL 'UQAR

(Elida Gusmira, Saifuddin Sa'dan \& Faisal Fauzan / 114-127)

TINJAUAN HUKUM ISLAM TERHADAP SISTEM PENYELESAIAN WANPRESTASI PRODUK ARRUM DI PEGADAIAN SYARIAH ACEH BESAR

(Asdi Marni, Edi Darmawijaya \& Faisal Fauzan / 128-136)

SANKSI ADAT BAGI PELAKU KEKERASAN FISIK DITINJAU MENURUT HUKUM PIDANA ISLAM (Studi Terhadap Adat Kampung Taman Firdaus, Kecamatan Pintu Rime Gayo, Kabupaten Bener Meriah)

(Abdul Rahman, Jamhuri \& Irwansyah / 137-144)

DAMPAK PEMEKARAN DAERAH PADA PELAYANAN PUBLIK DITINJAU MENURUT SISTEM HUKUM INDONESIA

(Ali Abubakar, Sitti Mawar \& Nurdin Syah / 145-155)

MARK UP PENJUALAN HARGA TIKET BUS PADA LOKET TERMINAL BATOH DALAM PERSPEKTIF TAS'IR AL-JABAR (Studi tentang Penyimpangan Harga Dari Ketetapan Organda Banda Aceh)

(Aris Rahmaddillah / 156-169)

PROSES PENIMBANGAN IKAN DI TEMPAT PELELANGAN IKAN LAMPULO KOTA BANDA ACEH DALAM PERSPEKTIF MA'QUD 'ALAIH

(Alfata / 170-175)

SANKSI BAGI PELAKU ZINA (Perbandingan Qanun No. 6 Tahun 2014 Dan Enakmen Jenayah Syariah Negeri Selangor No. 9 Tahun 1995 Seksyen 25)

(Ali Abubakar, Badrul Munir \& Cempaka Sari Harahap / 176-200) 
PETITA: Jurnal Kajian Ilmu Hukum dan Syariah

Volume 3, Number 2, 2018

P-ISSN: 2502-8006 E-ISSN: 2549-8274

DOI: https://doi.org/10.22373/petita.v3i2.47

\title{
TATACARA PENETAPAN BATAS TANAH DIKALANGAN MASYARAKAT KECAMATAN BAKONGAN TIMUR DITINJAU MENURUT KONSEP MAL 'UQAR
}

\author{
Elida Gusmira, Saifuddin Sa'dan \& Faisal Fauzan \\ Prodi Hukum Ekonomi Syariah \\ Universitas Islam Negeri Ar-Raniry Banda Aceh \\ Email: mirasyariah@gmail.com
}

\begin{abstract}
The problem concerning the land boundaries is the designation of land boundaries set by the landowner. Before the measurement of the land, the landowner must install pegs at each vertex of the boundary to be measured by the party determined. The measurement should be witnessed by the head of the village, the village officials, and the parties who are bordered with the land. The research problem was that the determination of boundary markers does not include the head of the village and the related parties bordered with the land. Instead, the landowner establishes the boundary markers by himself. The results indicated that all unresolved land boundary issues were due to the unwillingness of the community to report to the authorities. The procedure of land measurement should be conducted by placing pegs in advance on the land boundaries to be measured by the responsible party with several witnesses, and between the two the bordering parties, accompanied by the head of the village. This procedure controls the land boundary issues so it will cause no harm for the owner and other parties.
\end{abstract}

Keywords: Procedure, Determination of Land Boundaries, Mal 'Uqar Concept

Abstrak: Permasalahan penetapan batas tanah merupakan penunjukan batasbatas bidang tanah yang ditetapkan oleh pribadi (pemilik tanah itu sendiri) sebelum dilaksanakan pengukuran atas bidang tanah pemilik tanah harusmemasang patok pada setiap titik-titik sudut batas yang akan diukur oleh pihak yang telah ditentukan. Disaksikan oleh kepala desa, aparatur-aparatur desa, dan para pihak yang berbatasan tanah. Permasalahan yang terdapat dalam penelitian bahwa penetapan tanda batas tidak diikutsertai oleh kepala desa dan para pihak yang berbatasan tanah, akan tetapi pihak pribadi tanah mendirikan tanda batas dengan sendirinya. Seperti halnya yang terjadi lahan perkebunan oleh pemilik A yang berdekatan dengan pemilik B yang asal mula tidak ada tanda batas pada saat pemasangan tanda batas tidak disertai pemilik B dan telah melewati tanah pemilik B. Dalam penulisan ini penulis mengkaji bagaimana prosedur penetapan batas tanah dikalangan masyarakat Bakongan Timur serta bagaimana analisis Mal 'Uqar dalam penetapan batas tanah dikalangan masyarakat Bakongan Timur yang sebenarnya. Penelitian ini menggunakan metode deskriptif analisis dengan pendekatan kualitatif. Teknik pengumpulan data dilakukan dengan cara wawancara, observasi dan dokumentasi. Hasil dari penelitian menunjukkan bahwa segala bentuk permasalahan batas tanah ada yang belum terselesaikan dikarenakan ketidak inginan masyarakat untuk melaporkan kepada pihak berwajib, prosedur penetapan pengukuran tanah dengan cara memberi patok terlebih dahulu pada batas tanah yang akan diukur oleh pihak penanggung jawab dengan beberapa saksi dan antara kedua belah pihak yang berbatasan disertai kepala desa, dalam hal pengendalian permasalahan batas tanah agar tidak terjadi hal-hal yang tidak merugikan diri sendiri dan pihak lain.

Kata Kunci : Tatacara, Penetapan Batas Tanah, Konsep Mal ‘Uqar. 


\section{Pendahuluan}

Tanah merupakan salah satu sumber kehidupan bagi manusia, baik sebagai pendukung mata pencarian diberbagai bidang seperti pertanian, perkebunan, perternakan, maupun dipergunakan sebagai tempat untuk mendirikan perumahan sebagai tempat tinggal. Tanah juga merupakan sumber daya alam yang penting untuk kelangsungan hidup umat manusia, hubungan manusia dengan tanah bukan hanya sekedar tempat hidup akan tetapi lebih dari itu, tanah merupakan tempat dimana manusia hidup dan berkembang tanah menjadi sumber bagi segala kepentingan hidup manusia.

Penetapan batas tanah adalah penunjukan batas-batas bidang tanah dan pemasangan tanda batas yang di tetapkan oleh pribadi (pemilik tanah itu sendiri), masing-masing pihak pemilik tanah menetapkan batas bidang tanahnya sendiri, sebelum dilaksanakan pengukuran atas suatu bidang tanah pemegang hak atas tanah harus memasang tanda batas pada titik-titik sudut batas, serta harus ada penetapannya terlebih dahulu. Dimana dalam penetapan batas tanah harus dangan persetujuan atau diikut sertai oleh empat saksi atau lebih, dari tetangga yang berbatasan langsung dengan tanah tersebut, baik saksi tanah sebelah timur, barat, selatan, utara, yang harus ikut hadir dalam penetapan batas tanah pada saat melakukan pengukuran. Supaya tidak adanya keributan dikemudian hari, dan sebaiknya diikuti oleh beberapa keturunan dari para saksi. sebagaimana bidang tanah yang telah diberikan batasan dapat di perkuat atau didampingi oleh hukum adat yang dapat disaksikan oleh Geucik, Tuha peut, Tuha lapan, Ketua Gampong, kepala lorong, dan sebagainya atas dasar persetujuan bersama antara para pihak.

Data ukur letak batas bidang tanah yang dicatat dilapangan gambar ukur data tersebut disimpan dikantor pertanahan sepanjang masa sepanjang tanah tersebut masih ada dan masih menjadi hak miliknya, dikemudian hari data tersebut harus dapat digunakan untuk rekontruksi letak batas bidang tanah bila hilang. Pemilik tanah dan pemilik tanah berbatasan yang dapat hadir menyaksikan pengukuran dan menanda tanagani gambar ukur dengan membuat pernyataan bahwa tanda batas pada saat pengukuran atau penetapan batas tidak mengalami perubahan sebagaimana surat pernyataan kontradiktur sebelumnya.

Hal yang terjadi di Kecamatan Bakongan Timur yaitu permasalahan penetapan batas tanah para pihak yang berdekatan tanahnya diantara satu sama lain. ada berbagai permasalahan timbul pada tanah yang merupakan harta kekayaan benda tetap yang dimiliki oleh setiap masyarakat yang mana tanah ini merupakan harta kekayaan hak paten, semangkin hari semangkin meningkat pula harga atas tanah tersebut jadi masyarakat berlomba-lomba untuk memiliki tanah.

$M \bar{\alpha} l$ 'uqar atau sering disebut dengan ghair manqul ialah sesuatu harta yang tidak dapat dipindahkan dan dibawa kesuatu tempat yang lain seperti tanah, Rumah, Pabrik, dan Sawah. dalam Hukum Positif Ghair Manqul atau 'uqar disebut dengan istilah benda tetap. ${ }^{1}$

Menurut Jumhur Ulama yang dikutip oleh Nasroen Haroen. ${ }^{2}$ Al-mal yaitu segala sesuatu yang mempunyai nilai, dan dikenakan ganti rugi bagi orang yang yang merusak dan melenyapkannya. Tanah adalah suatu aset yang sumber penghasilan yang sebagian besar didapatkan dari tanah tersebut, maka tanah merupakan harta tetap.

'Uqar menurut Fukaha, hanyalah Bumi atau Kebun, baik kosong ataupun ada Rumah di atasnya. Rumah dan pepohonan dalam pandangan ulama Hanafiah dipandang Manqul. Karenanya tidak berlaku padanya hak Syuf'ah apabila yang dijual hanya rumah saja atau pepohonan kebun saja. Begitu pula tidak sah diwakafkan rumah saja, atau pepohonan saja 
didaerah yang penduduknya pernah mewakafkan rumah atau pepohonan saja, lantaran wakaf. Jelasnya rumah dan pepohan dalam pandangan Fiqh Hanafiah mempunyai dua tanggapan dipandang sebagai Mōl Manqul dihubungkan dengan kebun (Mōl Qhairul Manqul) atas dasar Tab'iyah.

\section{Landasan teori}

Harta dalam bahasa arab disebut Al-Mōl yang berasal dari kata yang berarti condong, cenderung, dan miring. $A l M \bar{\alpha} l$ juga dapat diartikan sebagai sesuatu yang dapat dimiliki yang termasuk bagian kehidupan manusia didunia, karena tanpa harta secara khusus seperti makanan maka manusia tidak dapat bertahan hidup. ${ }^{3}$ Oleh karena itu, Allah SWT menyuruh manusia memperolehnya memilikinya dan memanfaatkan bagi kehidupan manusia. Selain itu juga $m \bar{\alpha} l$ menurut istilah yang dikemukakan oleh Imam Hanafi ialah terkandung dalam kaidah berikut:

$$
\text { مايميل اليه طبع الإنسان ويمكن ادخاره الي وقت الحاجة او كان مايمكن حيازته واحرازه وينفع به. }
$$

"Segala yang diamati manusia dan dapat dihadirkan ketika diperlukan atas segala sesuatu yang dapat dimiliki, disimpan, dan dapat dimanfaatkan. ${ }^{4}$

Sedangkan Jumhur Ulama selain Imam Hanafi mengartikan harga sebagai berikut:

$$
\text { كل ما لله قيمة يلزم متثلفيها بضمانه }
$$

"Segala sesuatu yang mempunyai nilai dan dikenakan ganti rugi bagi orang yang merusak atau melenyapkannya."

Dalam kandungan kedua defenisi diatas terdapat perbedaan esensi harta yang dikemukakan oleh Imam Hanafi dan Jumhur Ulama yaitu menurut Imam Hanafi harta mesti dapat disimpan sehingga sesuatu yang tidak dapat disimpan tidak dapat disebut harta serta beliau berpendapat bahwa, manfaat tidak termasuk harta tapi manfaat termasuk dalam kategori milik. ${ }^{5}$ Sedangkan menurut Jumhur Ulama harta tidak hanya bersifat materi akan tetapi juga, didalam harta termasuk manfaat.

a) Dalam kamus Lisanul-'Arab Karay Ibnu Manzur diterangkan bahwa $M \bar{\alpha} l$ didefenisikan sebagai" segala sesuatu yang dimiliki."

b) Rasulullah dalam satu haditsnya menyatakan bahwa yang dimaksud dengan Idha'atul $M \bar{\alpha} l$ dalam hadits ini ialah menafkahkan dijalan yang haram, maksiat, atau pada halhal yang tidak disukai Allah.

c) Jadi pengertian harta (Mōl) dalam bahasa arab ialah apa saja yang dimiliki manusia. ${ }^{6}$ Pengertian harta dalam Al-Quran:

a. Dalam Al-Quran harta disebut dalam 25 surat dan 46 ayat. Menurut Muhammad Abdul Baqi, Al Mōl disebut 86 kali didalam beberapa ayat berikut ini. ${ }^{7}$

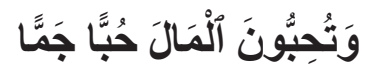

“ Dan kamu mencintai harta benda dengan kecintaan yang berlebihan." (Al-Fajar: 20)

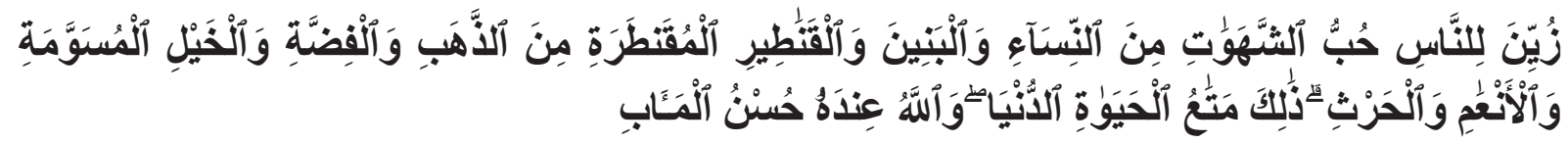

3 Amir Syarifuddin, Garis-Garis Besar Fiqh (Pranada Media 2003), hlm. 177.

Nasron haroen (n 2), hlm. 73.

Hendi Suhendi, Fiqih Muamalah (Raja Grafindo Persada 2007), hlm. 9.

Elis Mediawati, 'Harta Dalam Islam', hlm. 3.

Ibid. 
"Dijadikan indah pada (pandangan) manusia kecintaan kepada apa-apa yang diingini, yaitu: wanita-wanita, anak-anak, harta yang banyak dari jenis emas, perak, kuda pilihan, binatang-binatang ternak, [unta, lembu, kambing dan biri-biri] dan sawah ladang,"(Ali Imbran:14).

b. Jadi yang dimaksud dengan $M \bar{\alpha} l$ ( harta) itu berbeda-beda sesuai dengan tempat dimana kata-kata itu disebutkan dalam Al-Quran. Akan tetapi makna Mōl atau harta secara umum ialah segala sesuatu yang disukai manusia, seperti hasil pertanian, perak atau emas, ternak, atau barang lain yang termasuk perhiasan dunia.

Pengertian harta dalam as-sunnah:

1) Didalam kitab-kitab hadits terdapat banyak hadits yang mengandung kata $M \bar{\alpha} l$ (harta), diantaranya hadits Rasulullah.

2) Didalam hadist ini menunjuk bahwa hadits-hadits ini menunjukkan bahwa $M \bar{\alpha} l$ itu adalah nikmat Allah jika digunakan untuk kebaikan. Walaupun begitu, manusia tidak boleh menyembah harta dan menjadikannya sebagai tujuan hidup dunia dan lupa mengabdi kepada Allah.

3) Hadits-hadits ini secara tegas menahan penahanan atau penimbunan harta, menasionalisasikan (seperti sistem komunis) atau mengganggu harta seseorang oleh pemerintah tanpa alasan yang tegas. ${ }^{8}$

Pengertian harta menurut Ulama atau dalam Fiqh:

1) Segala sesuatu yang menyenangkan manusia dan mereka pelihara, baik dalam bentuk materi maupun dalam bentuk manfaat. ${ }^{9}$

2) Apa-apa yang memiliki manfaat yang mubah untuk suatu keperluan dan atau untuk kondisi darurat. (Ulama Hambali).

3) Barang-barang yang mempunyai nilai untuk dijual dan nilai harta itu akan terus ada kecuali kalau semua orang telah meninggalkannya (tidak berguna bagi manusia) kalau baru sebagian orang saja yang meninggalkan nya, barang itu masih dianggap harta karna barang itu mungkin masih bermanfaat bagi orang lain dan masih mempunyai nilai bagi mereka. (Imam Syafi'i).

4) Tidak ada yang bisa disebut $m \bar{\alpha} l$ (harta) kecuali apa-apa yang memiliki nilai penjualan dan diberi sanksi bagi orang yang merusaknya. Harta itu mengandung nilai (As-Sayuti).

5) Sesuatu yang layak dimiliki menurut syarat dapat di manfaatkan, disimpan atau dikuasai yang bersifat konkret (Mazhab Hanafi). ${ }^{10}$

6) Hasbi Ash-Shiddiqy membuat kesimpulan, bahwa yang termasuk harta ialah:

- Nama bagi selain manusia yang diciptakan allah untuk mencukupi kebutuhan hidup manusia, dapat diperlihara pada suatu tempat dan dikelola (Tasharuf) dengan jalan ikhtiar

- Sesuatu yang dapat dimiliki setiap manusia

- Sesuatu yang sah di perjual belikan

- Sesuatu yang dapat dimiliki dan mempunyai nilai harga

- Sesuatu yang berwujud

- Sesuatu yang dapat disimpan dalam waktu yang lama atau sebentar dan dapat

8 Ibid, hlm. 7.

$9 \quad$ Nasron haroen (n 2),hlm. 8.

10 Ibid, hlm. 8. 
diambil manfaatnya ketika dibutuhkan.

Pandangan Islam terhadap harta, Islam telah menetapkan hukum-hukum bagi masingmasing peruntukan harta itu yang menjamin harta tetap sebagai pelayan manusia untuk dimanfaatkan dan memberi manfaat kepada orang lain; bukan sebaliknya, yaitu manusia menjadi hamba dan pelayan harta dan menimbulkan bahaya bagi diri sendiri dan orang lain.

\section{Pengertian $M \bar{\alpha} l$ ' Uqar}

Istilah harta, atau Al-Mōl dalam Al-Quran maupun Sunnah tidak dibatasi dalam ruang lingkup makna tertentu, sehingga pengertian $A l-M \bar{\alpha} l$ sangat luas dan selalu berkembang. Pengertian harta $(M \bar{\alpha} l)$ dalam bahasa arab ialah apa saja ang dimiliki manusia. ${ }^{11}$

Harta dalam kamus besar Indonesia disebutkan bahwa harta adalah barang atau uang yang menjadi kekayaan berwujud dan tidak berwujud bernilai dan tidak bernilai menurut hukum dimiliki perusahaan.

Pengertian harta secara istilah (Terminologi), menurut defenisi harta yang berkembang dikalangan Fuqaha Hanafiyah, sebagai berikut:

1. Dimungkinkan untuk dimiliki, disimpan, dengan demikian $A l-M \bar{\alpha} l$ harus bersifat tangibel.

2. Secara lumrah (wajar), dan dimungkinkan untuk diambil manfaat Selain itu, kemanfaatan yang ada pada sesuatu.

Mōl 'Uqar merupakan Mōl Ghayru Manqul yang dapat diartikan sebagai harta tidak bergerak yang tidak dapat dipindahkan dari satu tempat ketempat yang lain seperti tanah.

Màl 'Uqar menurut Fukaha, hanyalah Bumi atau Kebun, baik kosong ataupun ada rumah di atasnya. Rumah dan pepohonan dalam pandangan ulama Hanafiah di pandang $M \bar{\alpha} l$ Manqul. Yaitu segala harta yang dapat dipindahkan dan dibawanya dari satu tempat ke tempat yang lain, karenanya tidak berlaku padanya hak Syuf'ah apabila yang di jual hanya rumah saja atau pepohonan kebun saja. Begitu pula tidak sah diwakafkan rumah saja, maka jika seseorang menjual rumah atau tanah yang terdapat pepohonan bersama-sama tanah. ${ }^{12}$

Menurut Fiqh Maliki, Rumah dan pepohonan dipandang 'Uqar, karena rumah itu melekat dengan tanah, dan tidak dapat dipindah dalam keadaannya itu. Sesudah dirombak baru dapat dipindah tanpa dirombak atau dirusak tidak dapat di pindah dalam pandangan Maliki, Rumah yang ada diatas kebun termasuk dalam pengertian 'Uqar. ${ }^{13}$

Dalam kaitan ini setiap pemilik harta tidak dapat mempergunakan hartanya sewenangwenang, akan tetapi juga tindakannya terhadap harta itu dibatasi atas pertimbangan terhadap kemaslahatan tetangga atau hak orang lain terutama jalan umum setapak yang merupakan milik pribadi namun tetap saja didalamnya terdapat hak bagi orang lain atau hak umum.

Adapun akibat hukum dari Mōl Uqar (harta tidak bergerak) terdapat beberapa pendapat para Ulama yaitu:

1. Berlakunya hak Syuf'ah (hak istimewa yang dimiliki seseorang terhadap rumah tetangganya yang akan dijual agar rumah itu terlebih dahulu ditawarkan kepadanya). Sebaliknya, apabila barang yang dijual adalah barang Manqul maka tidaklah dapat

11 Wahbah Az-Zuhaili, Fiqh Islam Wa Adillatuhu (Gema Insani 2011), hlm. 44.

12 Ahmad Wardi Muclish, Fiqh Muamalah (Amzah 2010), hlm. 63.

13 Ibid. 
ditetapkan dengan hukum Syuf'ah. Jika barang Manqul itu melekat pada 'Uqar maka hak Syufah itu dapat diberikan kepada keduanya. ${ }^{14}$

2. Menurut Ulama Hanafiah harta tidak bergerak boleh diwakafkan. Dalam masalah wakaf menurut Hanafiah berpendapat bahwa wakaf tidaklah sah kecuali harta itu harta 'Uqar. walaupun begitu jika harta 'Uqar yang diwakafkan tersebut melekat pada 'Uqar maka hukumnya adalah sah. Hal ini berbeda dengan pendapat Ulama lain yang menyatakan bahwa baik harta itu 'Uqar maupun Manqul keduanya dapat untuk diwakafkan. ${ }^{15}$

3. Seorang Al-Wasiy (orang yang diberi wasiat) yang berkewajiban memelihara harta anak kecil yang belum cakap hukum atau harta orang lain tidak dibenarkan untuk dijual harta tersebut kecuali dalam hal yang amat mendesak maka itu dibolehkan menurut syara' seperti untuk melunasi hutang memenuhi kebutuhan hidup yang primer dan lainnya yang jelas dengan kemaslahatan. Adapun harta Manqul dapat menjualnya kapanpun juga untuk memenuhi segala keperluan. Dalam masalah pelunasan hutang maka dalam penjualan barang hendaklah didahulukan harta Manqul kemudian baru diikuti dengan harta 'Uqar sekiranya tidak mencukupi.

4. Imam Abu Hanifah dan Sahabatnya, Abu Yusuf, berpendapat bahwa Al-Ģhașab tidak mungkin dilakukan pada harta tidak bergerak karena tidak mungkin memindahkan harta tersebut, karena mereka mengatakan bahwa salah satu syarat Al- Ghașab adalah dikuasai dan dipindahkan oleh pelaku Al-Ghașab, karena menurut mereka manfaat tidak termasuk dalam kategori harta. Sedangkan menurut Jumhur Ulama dan Muhammad Ibn Al-Hasan Asy-Syaibani, sahabat Imam Abu Hanifah lainnya, berpendapat bahwa Al- Ghașab boleh terjadi pada harta tidak bergerak karena menurut mereka manfaat suatu benda termasuk harta. Arti dari pada Al- Ghașab itu sendiri adalah mengambil sesuatu atau menguasai hak orang lain secara dhalim dengan cara terang-terangan. ${ }^{16}$

5. Dapat dibenarkan menjual kembali harta 'Uqar sebelum barang itu diterima oleh pembeli, sedangkan untuk harta Manqul tidak dibenarkan untuk menjual kembali barang tersebut kecuali apabila telah diterima oleh pembeli. Ini pendapat Abu Hanafiah dan Abu Yusuf.

6. Pada harta 'Uqar dapat juga hak tetangga dan hak penggunaan sedangkan harta Manqul tidak terdapat kedua hak ini ${ }^{17}$

7. Semua ahli Fiqh sepakat bahwa mustahil untuk harta Manqul untuk diambil paksa karena sesuatu hal, sedangkan menurut Abu Hanafiah dan Abu Yusuf harta 'Uqar lah yang mustahil untuk diambil paksa.

Hukum yang terkait dengan Mōl 'Uqar ialah, dalam pemanfaatannya tidak boleh memudharatkan orang lain dan tidak boleh memudharatkan pemilik lahan, serta apabila terkait dengan harta milik umum maka semua orang boleh memanfaatkannya dan begitupun jika terkait dengan harta milik pribadi maka pemanfaatan terhadap harta tidak bergerak tersebut harus seizin pemiliknya.

\footnotetext{
14 Ibid

15 Lebih lanjut tentang wakaf dan perannya sila rujuk, Saim Kayadibi, Zarinah Hamid and Norma Md Saad, 'The Contribution of Waqf Institutions in Malaysia and Turkey in Improving The Socio-Economic Conditions of The Society' (2017) 4 Turkish Journal of Islamic Economics 1 <http://dergipark.gov.tr/ beuntujise/issue/27708/292231>; Norma Saad, Salina Kassim and Zarinah Hamid, 'Best Practices of Waqf: Experiences of Malaysia and Saudi Arabia' [2016] Saad: Journal of Islamic Economics Lariba; Rozalinda Rozalinda, 'Peran Wakaf Dalam Pemberdayaan Ekonomi Perempuan' (2014) 2 Kafa`ah: Journal of Gender Studies 39 <http://kafaah.org/index.php/kafaah/article/view/40>.

16 Syekh Syamsudin Abu Abdillah, Pengantar Fiqh Imam Syafi'i (Mutiara Ilmu 2010), hlm 65.

17 Ibid.
} 


\section{Syarat-Syarat Mal 'Uqar}

Didalam Màl Al-Uqar terdapat beberapa syarat yang harus dipenuhi oleh pemilik harta, dimana didalam Mōl Al-Uqar tersebut terdapat hak orang lain. Adapun syarat-syarat $M \bar{\alpha} l$ 'Uqar yaitu:

1. Hak mempergunakan bersifat kekal mengikuti harta tidak bergerak

2. Hak menggunakan dikhususkan pada harta tidak bergerak.

3. Pemilik harta tidak boleh menutup jalan tersebut demi kepentingan umum

4. Tidak boleh dimiliki apabila harta tesebut digunakan untuk kepentingan umum seperti jalan raya, jembatan dan lain sebagainya. ${ }^{18}$

\section{Landasan Hukum Mal ‘ Uqar}

Dasar hukum Mal Al-Uqar didasarkan pada Firman Allah SWT dalam Surat Al-Hadid ayat:7 yang berbunyi:

\section{Al-Quran}

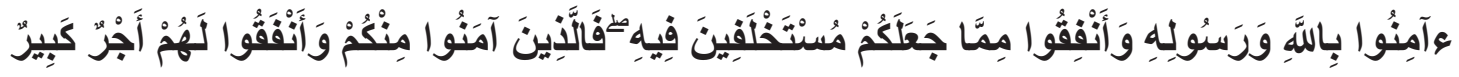

Artinya: "Berimanlah kamu kepada Allah dan Rasul-Nya dan infakkanlah (dijalan) Allah sebagian dari harta yang menjadikan kamu menguasainya, maka orangorang yang beriman di antara kamu dan menginfakkan hartanya di jalan Allah memperoleh pahala yang besar". (QS. Al-Hadid: 7) ${ }^{19}$

2. As-sunnah

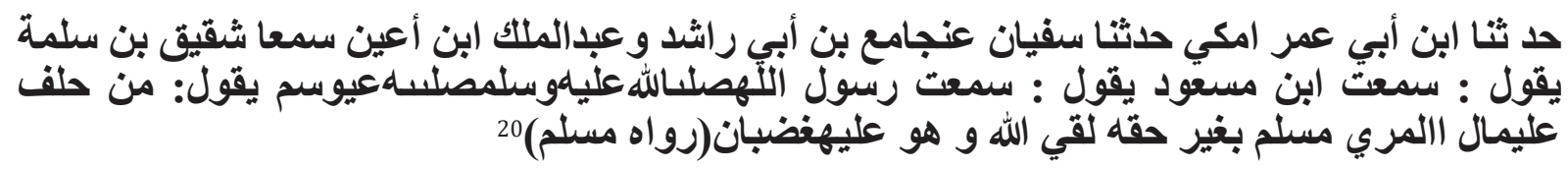

Artinya: “Diriwayatkan Ibn Abi Umar Al-Makkiyi diriwayatkan oleh Sufyan dari Jami’ Ibn Rasyid Dan Abdul Malik Ibn A'yan, telah Mendengar Syaqiq Ibn Salamah berkata: telah mendengar Ibn Mas'ud berkata telah mendengar Rasulullah SAW bersabda: barang siapa yang mengambil sebagian harta seorang muslim tanpa haknya, maka dia kelak akan bersumpah dengan Allah sedang Allah murka kepadanya". (HR. Muslim).

Berdasarkan ayat dan hadits diatas, dapat dikatakan bahwa seseorang akan menjadi pemilik dari harta yang telah ia usahakan sendiri dan dapat menguasai harta tersebut. Menguasai dan memiliki harta merupakan hak semua orang, dan pemilik harta tersebut berhak melindungi serta mempertahankan hartanya dari tindak kejahatan orang lain. Oleh karena itu, maka apabila seseorang mengambil hak orang lain secara batil maka itu merupakan perbuatan dosa. Namun, didalam kepemilikan harta pribadi tidak bersifat mutlak akan tetapi terdapat batasan-batasan tertentu dalam menggunakannya sesuai dengan ketentuan Syara'. Artinya, dalam menggunakan harta tidak boleh sewenangwenang yang dapat memudaratkan.

Ketentuan al-quran dan al-sunnah mengenai pengaturan kepemilikan kekayaan, antara lain:

'Pemanfaatan. Dari Ahmad, Abu Dawud, Tirmidzi, dan Adh Dhiyaa' dan dishahihkan oleh Syaikh al-Albani Nabi SAW bersabda:

18 Wahbah Al-Zuhailī, Al-Fiqh Al-Islāmī Wa Adillatuh, Jilid IV, (Dār al-Fikr 1986), hlm. 66.

19 M. Quraish Shihab, Tafsir Al-Mishbah Pesan, Kesan Dan Keserasian Al-Quran (Lentera Hati 2002), hlm. 15.

20 Imam Muslim, Shahih Muslim (Juz 1, Dar Al-Hadits 1997), hlm. 123. 


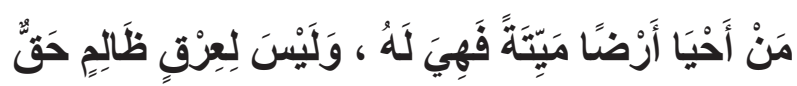

Artinya: "Barangsiapa yang menghidupkan tanah yang mati, maka tanah itu menjadi miliknya, dan bagi keringat yang zalim tidak ada hak." (HR. Ahmad, Abu Dawud, Tirmidzi, dan Adh Dhiyaa', dan dishahihkan oleh Syaikh al-Albani dalam Shahihul Jami' no. 5976)

Sebagai mana disebutkan dalam sebuah hadits dari Ahmad dan Tirmidzi, ia menyatakan "Hasan shahih", dan dishahihkan oleh Syaikh al-Albani dijelaskan bahwa Nabi SAW bersabda:

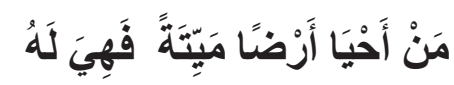

Artinya: " Siapa saja membuat suatu batas pada suatu tanah (mati) maka tanah itu menjadi miliknya"(HR.Ahmad dan Tirmidzi, ia menyatakan "Hasan shahih", dan dishahihkan oleh Syaikh al-Albani).

Dari uraian diatas dapat diambil inti sari sebagai berikut:

1. Seseorang yang memiliki satu bidang tanah wajib memasang batas pada sebidang tanah yang dimilikinya

2. Tanah yang telah dipasang tanda batas tersebut wajib diolah sendiri

3. Apabila dalam tiga tahun tidak diolah atau di telantarkan, maka pemilik tanah dapat kehilangan hak atas tanah

4. Hilangnya hak atas tanah oleh seseorang karena menelantarkan tanahnya, menjadi milik negara. Sehingga peraturan mengenai hal ini ditentukan negara dengan berdasar pada syariat islam. ${ }^{21}$

Sebagaimana yang disebut dalam al-quran surat al-isra' ayat 29 yang berbunyi:

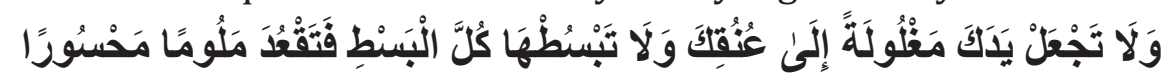

Artinya: Dan janganlah kamu jadikan tanganmu terbelunggu pada lehermu (kikir) dan janganlah kamu terlalu mengulurkannya (boros) karena itu kamu menjadi tercela dan menyesal (QS.Al-Isra':29)

Dari said bin zaid R.a bahwasanya Rasulullah SAW bersabda:

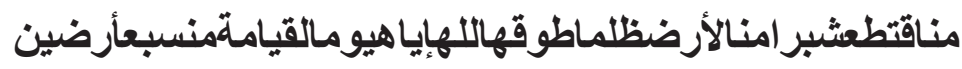

Artinya: Barang siapa yang mengambil sejengkal tanah secara zhalim, niscaya allah akan mengalungkan tanah tersebut kepadanya pada hari kiamat hingga tujuh lapis bumi. (diriwayatkan oleh al-Bhukari dan Muslim).

Gambar ukur adalah dokumen tempat mencantumkan gambar suatu bidang tanah atau lebih dan situasi sekitarnya serta data hasil pengukuran bidang tanah berdasarkan permohonan pemegang hak atau calon pemegang hak baru yang letaknya saling berbatasan, pemegang hak adalah orang atau badan hukum yang mempunyai hak atas tanah milik atau tanah pengelolaan atau nazir dalam hal tanah wakaf baik sudah terdaftar maupun belum terdaftar.

Patok merupakan sebuah alat yang digunakan untuk batas atas sebidang tanah, sehingga menjadi luas tanah yang dimiliki seseorang, patok yang merupakan tanda batas sangat penting adanya dikarenakan hal ini seringkali menimbulkan permasalahan dIbidang pertanahan seperti contoh yang akan dijelaskan dibab tiga yang menimbulkan sengketa tanah dikarenakan batas tanah yang melampaui milik orang lain atau bergeser. ${ }^{22}$

21 Al-Nabhani, An-Niham Al-Iqtishadi Fi Al-Islam (Darul Ummah 2004), hlm. 241.

22 Ibid. hal 69 
Secara fisik tanah mengalami perubahan baik karena faktor alam maupun peristiwa yang dilakukan oleh manusia, contonya seperti erosi, patok, tanah perpindah, tidak ada patok tanah yang jelas, bidang tanah yang dikelilingi pagar yang posisinya berdampingan dan dimanfaatkan pada saat yang sama maka pagar pembaginya mungkin akan merupakan pagar bersama, batas yang merupakan garis terletak ditengah-tengan garis pagar, tetapi sudah tentu bidang-bidang tanah berdampingan tidaklah selalu dimanfaatkan pada saat bersama.

Garis pembatas hanya merupakan suatu masalah persetujuan antara tetangga yang belum terungkap dalam surat pernyataan tertulis antara kedua belah pihak yang berbatasan tanahnya yang dikenal dengan asas kontradiktur. Penentuan letak batas dilakukan oleh pemilik tanah yang berbatasan, kebanyakan masalah umumnya batok tanah hanya berpatokan pada batok alam, seperti pohon, batas tanah tetangga, sehingga ini dapat menimbulkan permasalahan dIbidang pertanahan, dikarenakan hal ini seringkali dilakukan pengukuran ulang atas sebidang tanah.

Dasar penerbitan Surat Ukur adalah Gambar Ukur yaitu dokumen yang memuat hasil pengumpulan data fisik/pengukuran bidang tanah terhadap satu bidang tanah atau lebih dan situasi sekitarnya yang terdiri dari halaman pertama: nomor register Gambar Ukur, nomor peta pendaftaran, nomor foto udara, data letak bidang tanah (Kelurahan, Kecamatan, Kabupaten/Kota). Data identitas dan tanda tangan pemohon, data dan tanda tangan petugas ukur, hari dan tanggal pelaksanaan pengukuran, nama dan tanda tangan persetujuan tanda batas dari pemilik tanah tetangga yang berbatasan dan sket lokasi perkiraan dengan skala besar dari lokasi strategis seperti pasar, perempatan, masjid, sekolahan dan lain sebagianya; halaman kedua: data lapangan yaitu angka ukur baik berupa jarak, sudut, azimuth ataupun sudut jurusan, angka koordinat serta penetapan batas dengan skala pasti; halaman ketiga; Berita Acara/Laporan Kerja yang menguraikan dasar hukum pelaksanaan pengukuran (tanggal dan nomor surat tugas), hari dan tanggal pelaksanan pengukuran serta hal-hal yang diperoleh dalam pelaksanaan pengukuran seperti; letak tanah, status hak, nama pemilik tanah, tanda batas yang dipasang, ada atau tidaknya permasalahan dengan pihak lain, riwayat status tanah dan lain-lain yang ditanda tangani oleh petugas ukur dan diketahui aparat kelurahan/desa letak tanah. ${ }^{23}$

Bukti hak atas tanah disebut dengan Sertifikat. Sertifikat merupakan hasil dari kegiatan pendaftaran tanah yang merupakan realisasi dari tujuan Undang-Undang Pokok Agraria, dimana "kegiatan pendaftaran tanah akan menghasilkan tanda bukti hak atas tanah yang disebut dengan Sertifikat". ${ }^{24}$ Sertifikat tanah terdiri dari dua bagian yaitu buku tanah dan surat ukur yang dirangkai menjadi satu kesatuan yang tidak terpisahkan. Buku Tanah adalah dokumen yang memuat data yuridis dan data fisik suatu obyek pendaftaran tanah yang sudah ada haknya. Surat Ukur adalah dokumen yang memuat data fisik suatu bidang tanah dalam bentuk peta dan uraian data fisik tanah, yang terdiri dari luas, menunjukkan letak bidang tanah baik desa/kelurahan, kecamatan maupun provinsi, nomor lembar peta, punujuk batas, maupun nama petugas ukur yang melakukan pengukuran bidang tanah tersebut.

\section{Metode Penelitian}

Metode Penelitian yang digunakan dalam pembahasan skripsi ini adalah jenis deskriptif analisis yaitu penelitian yang dimaksudkan untuk menyelidiki keadaan, peristiwa, kondisi, kegiatan dan hal-hal lain, yang hasilnya dipaparkan dalam bentuk laporan penelitian.

23 Ali Achmad Chomzah, Hukum Pertanahan (Prestasi Pustaka 2002), hlm. 123.

24 Maria SW. Sumardjono, Kebijakan Pertanahan Antara Regulasi Dan Implementasi (Buku Kompas 2001), hlm. 81. 
Disini penulis juga memaparkan dan menggambarkan tentang tatacara penetapan batas tanah dikalangan kecamatan bakongan timur ditinjau menurut konsep mal uqar. Untuk memeperoleh data yang sesuai dengan objek penelitian berupa data primer dan data sekunder, maka penulis menggunakan metode field research (penelitian lapangan), yaitu penelitian yang merupakan metode pengumpulan data dengan cara tanya jawab yang dikerjakan sistematik dan berlandaskan pada objek, masalah, dan tujuan penelitian. ${ }^{25}$ Selanjutnya, penulis menggunakan metode library research (penelitian kepustakaan), yaitu menggali teori-teori yang telah ada atau berkembang sesudahnya untuk menggali setiap hal yang berkepentingan dengan substansi skripsi dan untuk mengetahui atau membandingkan, sejauh mana hubungan ilmu dari teori buku yang ada dan kesimpulan data yang didapatkan. ${ }^{26}$

Dalam mengumpulkan data penulis menggunakan teknik wawancara, dan dokumentasi. Adapun yang penulis wawancarai yaitu aparatur desa Seuleukat dan warga desa Seuleukat serta aparatur laiannya. Adapun dokumentasi merupakan cara yang dilakukan untuk menyediakan dokumen-dokumen dengan menggunakan bukti yang akurat dari pencatatan sumber informasi, menganalisis dokumen, laporan kegiatan, serta informasi lainnya yang berkaitan dengan penelitian yang akan dibahas dan dikaji.

\section{Hasil Penelitian Dan Pembahasan}

\section{Proses Penetapan Tanah Di Kalangan Masyarakat Bakongan Timur.}

Masyarakat Bakongan Timur masih hidup dalam lingkungan kebudayaan yang berprinsip pada hukum adat yang menjunjung tinggi nilai-nilai kebersamaan dan kekeluargaan, bagi masyarakat Bakongan Timur tanah merupakan harta yang sangat berharga sebagai tempat pencari hafkah dan mempertahankan keberlangsungan hindupnya, disebabkan terlalu pentingnya tanah dalam kehidupan masyarakat Bakongan Timur sehingga menyebabkan terjadinya kesalah pahaman yang ujung-ujungnya terjadi persengketaan.

Sengketa Pertanahan adalah perselisihan pertanahan antara orang perseorangan, badan hukum, atau lembaga yang tidak berdampak luas secara sosio-politis. Salah satu faktor penyebabnya adalah kegagalan komunikasi antar pihak ataupun karena para pihak yang masih awam terhadap masalah-masalah dalam bidang pertanahan. ${ }^{27}$

Faktor penyebab terjadinya sengketa tanah dalam hidup bermasyarakat biasanya terjadi dikarenakan beberapa faktor :

\section{Status tanah yang tidak pasti}

Yang dimaksud dengan ketidak pastian merupakan permasalahan status tanah yang tidak mempunyai kekuatan badan hukum, dalam kehidupan Masyarakat Bakongan Timur bukti surat akan tanah sendiri diperoleh dari kekuatan hukum lokal diatas materai, terlebih lagi pada masyarakat yang berada jauh dari pusat perekonomian. ${ }^{28}$

2. Masalah penjualan tanah yang tidak jelas ukurannya

Masyarakat Bakongan Timur dahulunya dalam berbagai harta warisan bahkan dalam penjualan tanah yang didasarkan sejauh orang tua melempar bibit tanaman. Kondisi seperti ini akan dapat menimbulkan masalah menjadi semakin rumit, semisal orang tua yang mewariskan tanah kepada anaknya meninggal dunia akhirnya meninggalkan

25 Moh. Pabundu Tika, Metodologi Riset Bisnis (PT Bumi Aksara 2006), hlm. 62

26 Moh. Nazir, Metode Penelitian (Ghalia Indonesia 2003), hlm. 93.

27 Universitas Diponegoro., 'Penyelesaian Tanah Non Litigasi Di Kab. Konawe Sulawesi Tenggara' (Universitas Diponegoro.) <www.eprints@undip.ac.id>.

28 Dominiria Hulu, Sengketa Tanah Dan Prosedur Penyelesaiannya, (Fakultas ilmu Sosial dan Ilmu Politik, USU 2009), hlm. 117. 
konflik berkepanjangan dalam kehidupan anak cucunya kelak.

Pada dulunya sistem tersebut sah-sah saja berlaku karena tanah pada zaman nenek monyang cukup luas, akan tetapi yang disayangkan kondisi sekarang tidaklah menunjang keberlakuannya cara demikian malah lambat laun sistem yang digunakan dulunya malah punah disebabkan cucu-cucunya memperoleh warisan berupa tanah tidak akan mendapat warisan.

\section{Masyarakat Bakongan Timur yang merantau}

Permasalahan yang terjadi pada tanah juga dikarenakan situasi keluarga, dikarenakan desakan ekonomi dan juga pencarian ilmu sehingga kurang faham dalam mengelola lahan pertanian menjadikan anak-anak dari orang tua yang akan mewariskan tanah orangtuanya. Anak yang telah lama merantau dan tanda mengetahui batas tanah dari orang tuanya akan menjadi suatu masalah di kemudian hari dan akan menjadi rumit apabila orang tua dari sianak meninggal dunia.

Maka adapun contoh kasus permasalahan batas tanah yang terjadi pada masyarakat Bakongan Timur Desa Seuleukat yang didasarkan beberapa faktor diatas yang terjadi pada masyarakat pada umumnya yaitu:

Dari hasil wawancara penulis dengan aparatur Desa Suleukat sampai saat ini belum ada yang memperbesarkan masalah-masalah batas tanah hanya saja salah satu warga desa yang bersengketa tanah yang mana penyelesaiannya sampai ke pengadilan akan tetapi objek tanah yang disengketakan bersebelahan dengan Desa Seuleukat yaitu objeknya terletak didesa Gunung Kapur, selain dari itu masalah sengketa batas tanah maupun masalah sengketa tanah yang lainnya penyelesaiannya hanya sampai ke tangan aparatur desa, dapat diselesaikan tidak sampai ke Geucik (kepala desa). ${ }^{29}$ Masalah tersebut akan difasilitasi oleh aparatur dusun masing-masing, lebih dari itu warga yang memiliki masalah dengan tanah hanya menyelesaikan secara kekeluargaan atau sesamanya saja adapun masaalahnya ada akan tetapi tidak di laporkan hanya mendiaminya sehingga masalah tersebut hilang dengan sendirinya. ${ }^{30}$

Adapun kasus pertama di desa Seuleukat, jauh sebelumnya kasus sengketa tanah mulai muncul seperti halnya kasus yang terjadi dimasyarakat desa salah satu warga bernama Ibu Zaidah yang berbatasan tanah rumahnya dengan tetangga sebelahnya, dimana Ibu Zaidah merasa dirugikan bahwa hal yang terjadi merupakan tetangga Ibu zaidah bernama Ibu Zian. Permasalahannya, sebelumnya Ibu Zaidah dan Ibu Zian saling berbatasan tanah dimana tanah tersebut tidak ada sesuatu membatasi tanah yang dibuat oleh keduanya, Ibu Zaidah hanya membuat tanda bahwa ada sebatang pohon salam diperbatasan tanah mereka. Sejauh ini pihak tetangga Ibu Zian telah mendirikan atau membuat pagar batas tanahnya tanpa memanggil pihak sebelahnya yaitu Ibu Zaidah untuk menyepakati apakah telah sesuai dalam perbatasan tanah. Akan tetapi sejauh ini Ibu Zaidah melihat pagar yang telah didirikan dengan kayu telah mengelilingi rumahnya serta melihat bahwa pohon salam yang telah tumbuh besar diperbatasan tanah antara kedua belah pihak telah jauh bergeser kedalam pagar Ibu Zian kurang lebih sekitar tiga langkah telah melewati pohon salam dengan pagar yang telah dibuat. Akan tetapi Ibu Zaidah tidak melaporkan hal atau

29 'Hasil Wawancara Dengan Bapak Jhon Palapa, Jam 21:25 Wib.' Tentang teknik penyelesaian sengketa dengan model yang serupa sering ditemukan di berbagai tempat, teknik ini sering disebut dengan Mediasi. Pembahasan lebih lanjut mengenai mediasi sila rujuk, Nia Kurniati, "Mediasi-Arbitrase" Untuk Penyelesaian Sengketa Tanah' (2016) 18 Sosiohumaniora $197<$ http://jurnal.unpad.ac.id/ sosiohumaniora/article/view/10008>; Sri Hajati, Agus Sekarmadji and Sri Winarsi, 'Model Penyelesaian Sengketa Pertanahan Melalui Mediasi Berkepastian Hukum' [2014] Jurnal Dinamika Hukum.

'Hasil Wawancara Dengan Liswardi, Tanggal 10 July 2018, Jam 11:30 Wib.' 
permasalahan tersebut kepada aparatur desa dikarenakan tidak ingin ada keributan, permusuhan antara sesama tetangga. ${ }^{31}$

Kasus kedua, kasus yang sama antara Ibu Aisyah dengan Ibu Nurhayati yang saling berbatasan tanah rumah, dimana pada saat pembuatan pagar yang terbuat dari kayu telah melewati sedikit tanah Ibu Aisyah maka Ibu Aisyah tidak mempermasalahkannya dikarenakan sedikit tanah yang bergeser, maka pagar yang terbuat dari kayu lama kelamaan akan hancur terbuai dikarenakan rapuh terkena air hujan dan sinar matahari maka pagarnya akan hancur pada waktunya. Dengan itu pada saat Ibu Nurhayati membuat pagar baru sedikit bergeser dari pagar yang sebelumnya, akan tetapi buk aisyah tidak juga melakukan pelaporan terhadap aparatur desa dikarenakan tidak ingin ada keributan antara sesama tetangga dan juga tidak ingin di ketahui oleh semua masyarakat nantinya bahwa ada keributan sesama tetangga. Permasalahannya juga terjadi bahwa Ibu Nurhayati pada saat pemasangan batas yang berupa pagar dari kayu-papan tidak memanggil para pihak yanng berbatasan tanah dengan nya.

\section{Pengesahan Batas Tanah Dalam Hukum Islam}

Islam mengatur dan mengakui hak milik seseorang, baik hak itu digunakan ataupun tidak, baik dipinjamkan kepada pihak lain maupun terbengkalai, hak milik disini baik berupa hak atas tanah, hak atas bangunan, harta yang bergerak dan hak kepemilikan lainnya.

Tanah merupakan harta ghair manqul artinya tanah merupakan harta yang tidak dapat dipindahkan dan dibawa-bawa. ${ }^{32}$ Harta dalam bentuk ini tidak hanya berupa tanah tetapi dapat juga dalam bentuk rumah, pemukiman, perusahaan dan lain sebagainya yang bersifat tidak bisa dipindahkan dan dibawa-bawa. Menurut islam, kepemilikan harta kekayaan baik berupa tanah maupun yang lainnya pada manusia terbatas pada kepemilikan kemanfaatannya selama masih hidup didunia, dan bukan kepemilikan secara mutlak. Saat dia meninggal, kepemilikan tersebut berakhir dan harus didistribusikan pada ahli warisnya sesuai ketentuan syariah. ${ }^{33}$ Karena kepemilikan yang hakiki hanya milik Allah, dan kepadanyalah semua akan dikembalikan.

Analisis hukum Islam dalam kasus pertama dan kedua. bahwa tentang perbuatan pengambilan tanah milik orang atau bisa disebut dengan pergeseran batas terhadap tanah merupakan perbuatan zalim yang banyak terjadi di masyarakat. Merampas tanah dengan mengubah batas tanah dengan tanah adalah sebuah perbuatan zalim yang banyak terjadi dimasyarakat, termasuk juga yang dilakukan oleh banyak petani maupun warga biasa yang bermasalah dengan batas tanah rumah. Perbuatan ini banyak dianggap sebagai perkara yang sepele dimasa sekarang, mereka para pelaku perbuatan ini menganggap remeh perkara ini bahkan menganggap hal yang biasa terjadi dimasyarakat. Imam AdDzahabi mencantumkan bab mengubah batas tanah termasuk kedalam dosa-dosa besar yang membinasakan terdapat dalam kitabnya Al-Kabair mengenai masalah mengambil tanah orang lain tanpa izin pemiliknya telah dijelaskan pada hadits yang tertulis dalam bab dua diatas.

Dikaitkan dengan pengukuran tanah telah dijelaskan diatas bahwa pada saat melakukan pengukuran dan membuat tanda batas terhadap tanah maka harus dihadiri oleh para pihak yang berbatasan tanah dengannya, dihadiri oleh kepala desa, aparatur desa lainnya, orang yang faham masalah batas tanah terkait. Dapat dilihat pada studi kasus diatas bahwasanya aplikasi pada permasalahan hanya membuat pagar dengan sendirinya tidak dihadiri oleh para saksi setidaknya lebih kurang dihadiri oleh para pihak yang berbatas tanah untuk

31 'Wawancara Dengan Buk Zaidah, Pada Hari Kamis, Tanggal 19 July, Jam 17:57'.

32 Hendi Suhendi, Fiqh Muamalah (PT Raja Grafindo Persada 2007), hlm. 22.

33 Sri Nurhayati dan Wasilah, Akuntansi Syariah Di Indonesia (Selemba Empat 2011), hlm. 67. 
dapat kepastian atas dasar kesepakatan para pihak terhadap batas berupa pagar yang akan dibuat, dan tanda perbatasan tanah tidak hanya berpatok pada tumbuhan alam saja akan tetapi ada aturan yang harus dijalankan untuk ketentraman dalam hal masalah batas tanah.

Dalam artian perbuatan yang dilakukan oleh masyarakat telah melanggar aturan yang telah ditentukan oleh hukum, baik itu hukum adat, hukum negara maupun yang terlebih pentingnya melanggar hukum islam, bahwasanya masyarakat telah senantiasa atau telah terbiasa untuk mendirikan pagar sebagai tanda batas tanah dengan sendiri.

\section{Kesimpulan}

Setelah membahas data-data yang yang penulis peroleh dari penelitian di Kecamatan Bakongann Timur maka dapat di ambil beberapa kesimpulan sebagai berikut: Dengan adanya prosedur pengukuran tanah yang jelas tentu kedepannya akan semakin menjadi kemantapan bagi pemilik tanah atau pembeli tanah, oleh karena itu proses pengukuran batas tanah sangatlah penting. Prosedur penetapan tanah di Bakongan Timur, pengukuran tanah dengan cara memberi tanda batok terlebih dahulu pada batas tanah yang akan diukur oleh aparatur desa yang disaksikan oleh kepala desa, para pihak yang berbatasan tanah, saksi seperti keturunan dari para pihak yang berbatasan tanah.

Analisis terhadap penetapan batas tanah dikalangan masyarakat kecamatan Bakongan Timur yang sebagian tidak sesuai dengan aturan yang telah di tetapkan, sebagaimana bahwa pada saat pembuat batas tanah yang seharusnya dihadiri oleh para saksi dan antara kedua belah pihak yang berbatasan tanah untuk mendapatkan persetujuan batas dalam mendirikan sebuah pagar pada tanah. Penjualan terhadap tanah yang dilakukan oleh beberapa masyarakat Bakongan Timur tidak sesuai dengan batas yang tertera didalam surat pengukuran tanah, yaitu penjual tanah telah melakukan wanprestasi terhadap tanah yang dijual sehingga dapat merugikan sebelah pihak.

\section{Daftar pustaka}

Abdul Rahman Ghazaly, Fiqh Muamalat (Kencana 2010)

Abu Abdillah SS, Pengantar Fiqh Imam Syafi'i (Mutiara Ilmu 2010)

Ahmad Wardi Muclish, Fiqh Muamalah (Amzah 2010)

Al-Nabhani, An-Niham Al-Iqtishadi Fi Al-Islam (Darul Ummah 2004)

Al-Zuhailī W, Al-Fiqh Al-Islāmī Wa Adillatuh (Dār al-Fikr 1985)

Ali Achmad Chomzah, Hukum Pertanahan (Prestasi Pustaka 2002)

Amir Syarifuddin, Garis-Garis Besar Fiqh (Pranada Media 2003)

Az-Zuhaili W, Fiqh Islam Wa Adillatuhu (Gema Insani 2011)

Dominiria Hulu, Sengketa Tanah Dan Prosedur Penyelesaiannya, (Fakultas ilmu Sosial dan Ilmu Politik, USU 2009)

Elis Mediawati, 'Harta Dalam Islam'

Hajati S, Sekarmadji A and Winarsi S, 'Model Penyelesaian Sengketa Pertanahan Melalui Mediasi Berkepastian Hukum' [2014] Jurnal Dinamika Hukum

'Hasil Wawancara Dengan Bapak Jhon Palapa, Jam 21:25 Wib.'

'Hasil Wawancara Dengan Liswardi, Tanggal 10 July 2018, Jam 11:30 Wib.' 
Hendi Suhendi, Fiqh Muamalah (PT Raja Grafindo Persada 2007)

——, Fiqih Muamalah (Raja Grafindo Persada 2007)

Imam Muslim, Shahih Muslim (Juz 1, Dar Al-Hadits 1997)

Kayadibi S, Hamid Z and Saad NM, 'The Contribution of Waqf Institutions in Malaysia and Turkey in Improving The Socio-Economic Conditions of The Society' (2017) 4 Turkish Journal of Islamic Economics 1 <http://dergipark.gov.tr/beuntujise/ issue/27708/292231>

Kurniati N, “"Mediasi-Arbitrase” Untuk Penyelesaian Sengketa Tanah' (2016) 18 Sosiohumaniora $197<$ http://jurnal.unpad.ac.id/sosiohumaniora/article/ view/10008>

M. Quraish Shihab, Tafsir Al-Mishbah Pesan, Kesan Dan Keserasian Al-Quran (Lentera Hati 2002)

Maria SW. Sumardjono, Kebijakan Pertanahan Antara Regulasi Dan Implementasi (Buku Kompas 2001)

Moh. Nazir, Metode Penelitian (Ghalia Indonesia 2003)

Moh. Pabundu Tika, Metodologi Riset Bisnis (PT Bumi Aksara 2006)

Nasron haroen, Fiqh Muamalah (Gaya Media Pretama 2007)

Rozalinda R, 'Peran Wakaf Dalam Pemberdayaan Ekonomi Perempuan' (2014) 2 Kafa'ah: Journal of Gender Studies 39 <http://kafaah.org/index.php/kafaah/article/ view/40>

Saad N, Kassim S and Hamid Z, 'Best Practices of Waqf: Experiences of Malaysia and Saudi Arabia' [2016] Saad: Journal of Islamic Economics Lariba

Sri Nurhayati dan Wasilah, Akuntansi Syariah Di Indonesia (Selemba Empat 2011)

Universitas Diponegoro., 'Penyelesaian Tanah Non Litigasi Di Kab. Konawe Sulawesi Tenggara' (Universitas Diponegoro.) <www.eprints@undip.ac.id>

'Wawancara Dengan Buk Zaidah, Pada Hari Kamis, Tanggal 19 July, Jam 17:57' 